Orbis Tertius, vol. XXIV, nº 29, e116, mayo-octubre 2019. ISSN 1851-7811

Universidad Nacional de La Plata

Facultad de Humanidades y Ciencias de la Educación

Centro de Estudios de Teoría y Crítica Literaria

\title{
Jorge Monteleone, El centro de la tierra: Lectura e infancia. Buenos Aires, Ampersand, 2018, Lector\&s, 222 páginas
}

En la primera página, inmediatamente después de la dedicatoria, una cita de la banda alemana Die Toten Hosen abre el libro. Además de recordarnos la afinidad de Jorge Monteleone por el rock, la cita nos dice, si la traducimos, algo así: "En días como estos,/ Deseamos infinidad/ En días como estos, todavía tenemos mucho tiempo, (...)/ Ningún final a la vista" (p. 5). Los temas del libro, la lectura y la infancia, se podrían entonces caracterizar como los días evocados en la canción: idílicos, lejanos e infinitos, capaces de conjurar la muerte. Pues se trata de un libro sobre la muerte, pero también sobre la felicidad: "Luego llegaba el ensueño del comienzo. Y abría los libros y comenzaba a leer. Comenzar no era hojearlo sino leer la primera página y continuar hacia delante llevado por la marea. Desde entonces los comienzos, como los versos recordados, me frecuentan y me asaltan, al igual que a todos los obsedidos por la lectura, y de modo invariable son el señuelo de la felicidad" (p. 125).

El centro de la tierra: Lectura e infancia es un libro que se propone como autobiografía literaria. Incluido en la colección Lectorés dirigida por Graciela Batticuore y compuesto de treinta y un capítulos o ensayos breves, se trata de la historia de la formación de un lector. Este lector podría ser Jorge Monteleone o podría ser cualquiera: la reminiscencia de textos tan clásicos y universales (pero que para el lector temprano significaron experiencias intransferibles) hace que la lectura de esta biografía se vuelva una experiencia del reencuentro con lo íntimo para quienes se aproximan a ella. Pues nosotros, también, terminamos levantando la cabeza de la lectura de vez en cuando para preguntarnos: ¿cómo me hice lector/a?

La autobiografía de Jorge Monteleone constituye así una invitación al ejercicio de la memoria y una vuelta a la propia infancia: Verne, Juan Ramón Jiménez, los Looney Toons, las historietas de superhéroes, Stevenson, la Billiken, Anteojito, entre otros textos y productos culturales masivos, atraviesan estas páginas de manera desordenada y aleatoria, en un movimiento de ida y vuelta y repeticiones en el que la linealidad del tiempo se desdibuja y los asaltos de la memoria se vuelven el modo de contar una historia.

Al mismo tiempo, también hacen su aparición las lecturas que, con el correr de los años, fueron expandiendo ese mundo literario primigenio, pero sin perder de vista ese origen que está en la infancia. Neruda, Tuñón, Borges, Rulfo, Proust, Aira, Dostoievski, Baudelaire, forman parte de su biblioteca y en todos ellos hay ecos de la infancia:

Al recordar este cómic [se refiere a las historietas de Gene Ahern que leía de niño] vuelve a mí uno de los libros más felices de César Aira: su ensayo Edward Lear, que contiene abundantes limericks (...). Entonces aquellos cómics de Gene Ahern cuyo nombre ignoraba eran el anticipo y a la vez el resultado del nonsense que podía comprender en los dibujos y los poemas de Lear (p. 92).

De esta forma, a lo largo del libro, Monteleone va entretejiendo, para el relato de su devenir en lector, los recuerdos de su iniciación literaria con vivencias personales: los momentos de su alfabetización en la escuela primaria, la influencia fundamental de su abuelo Rosario Favazzi, la presencia dolorosa de su madre, 
signada por el fantasma del suicidio (pero también por el recuerdo del aprendizaje de la lengua materna y de la superación de la página en blanco). La apuesta del libro está en la relación constante entre literatura y vida: el repaso de los días en que su abuela sufría de aterosclerosis e iba perdiendo la memoria, por ejemplo, viene unido a la rememoración de la lectura de Pedro Páramo, que representó en ese momento tan crítico un refugio: "a eso estaba acostumbrado desde chico, a salvarme con un libro o a salvar con un libro la maldición de la hora y olvidar la muerte” (p. 31).

Sin embargo, no todo aquí pertenece al ámbito de la literatura, los programas televisivos o las historietas. Entre los libros consumidos (devorados como por el demonio de Tasmania, a quien se refiere en $L a$ divergencia al hablar de su hambre de lecturas) y los relatos familiares, también se cuela la teoría literaria. Pero no como un discurso que se pretende didáctico y que viene a formalizar las lecturas, acomodarlas en una estructura o darles un sentido; sino que se suma, como uno más, a esos relatos que conforman el universo del lector. Algunos capítulos, además de dar cuenta de momentos significativos de su vida, relacionados con la lectura, vuelven sobre temas y discusiones que han ocupado un lugar preponderante en la trayectoria de Monteleone como crítico. El ensayo que abre el libro, La infancia y elparaíso, es una reflexión sobre el estatuto filosófico de la infancia, en donde resuenan las ideas de Agamben (la infancia como momento en que el hombre, el infante, no hablaba) y de los románticos Novalis y Hölderlin (la infancia como paraíso). Entre ellas, se insertan las ideas del propio Monteleone:

Cuando el yo pasa de ser infante a hablante, entra en el mundo simbólico, entra en la historia, pero la verdadera experiencia está allí: latente. Creo algo más, siquiera como una fe que se distrae del derrumbe: que la lectura le da a esa infancia un mundo, y que con los años tal vez se despierta de nuevo ese mundo de la infancia en el acto mismo de leer (p. 15).

En El habla de las cosas, por otra parte, aparece una de las fascinaciones de Monteleone, que se repetirá en varios de los ensayos subsiguientes: el mundo de la materia y de los objetos. Allí, el crítico relata, de manera parecida a como lo hizo en su ponencia Lectura e infancia leída en el I Congreso Internacional CeLeHis (y en la cual este libro puede quizás encontrar una de sus raíces), la manera en que Proust se refiere a sus lecturas de infancia:

Cuando Marcel Proust recuerda los días de lectura en la infancia, lo evocado es menos lo leído que las horas en las cuales el mundo era objeto de la atención del niño. (...) Esa "vida" que interrumpe la lectura es la vida cotidiana de las acciones, los intercambios y la charlatanería que los adultos ocupan, pero no toda la realidad: no es, por ejemplo, la vida inherente a las cosas del mundo. Porque ellas no solo no interrumpen la lectura, sino que la intensifican (p. 17).

\section{También se lee en El galpón:}

Atribuyo mi afición a tomar el partido por las cosas dando un largo rodeo por las palabras que se acumulan en los poemas -como decía Francis Ponge- a la experiencia de ese lugar, en el cual nos quedábamos horas y horas jugando con mi primo Hugo, donde yo leía todo lo que podía encontrar acumulado entre papeles viejos (...) (p. 175).

Una de las invenciones más novedosas del libro es la incorporación de largos paréntesis en medio de los ensayos, quizás para suplantar las notas al pie o las notas al final en lo que estas tienen de ilegible (por la interrupción que producen, además de constituir dispositivos mucho más académicos). Por el contrario, los paréntesis, de manera armónica, añaden detalles a lo que está siendo contado en el cuerpo del texto, y en muchas ocasiones es el lugar donde aparecen la teoría y otros conocimientos enciclopédicos.

Lejos de apuntar a su formación como intelectual, culto o letrado, esta autobiografía hace foco en lo que la infancia tiene para decir, todavía, al crítico, puesto que constituye una potencia infinita que, a medida que se aleja, regresa con fuerza en las lecturas. La infancia se configura como un espacio irrecuperable pero restante, en donde sólo existía el lector y aún no nacía el crítico. En ese sentido, se podría afirmar sin dudas que el libro cumple con su deseo de libro infinito (a la manera de Mallarmé) que busca una y otra vez el centro, el grado cero de su propia escritura: "Mi libro ideal debería ser así: puede comenzar en cualquier parte 
y ese comienzo sería aleatorio y no debería terminar nunca o debería recomenzar cíclicamente, de un modo igualmente aleatorio cada vez que el lector diera con el mismo capítulo" (p. 9).

Inagotable por su naturaleza heterogénea (¿memorias? ¿ensayo? ¿diario de lecturas?) y por la increíble vastedad de obras mencionadas, El centro de la tierra: Llectura e infancia se nos da como una autobiografía extraña, híbrida y magistral en donde la vida se convierte en materia literaria. Su lectura resulta amena y luminosa, gracias a la prosa de un autor que, como puede apreciarse al leer el resto su obra, dista mucho del discurso académico al que la crítica nos tiene acostumbrados; por el contrario, constituye una experiencia estética que nos reenvía al segundo postulado del romántico Friedrich Schlegel, parafraseado por Alberto Giordano en La resistencia a la ironia: notas desde (hacia) los ensayos de Borges: "Sólo la literatura en estado de interrogación y busca de sí misma puede comprender reflexivamente la ley de su engendramiento" (2015, p. 103).

Para concluir, se podría arriesgar que, nuevamente debido al enorme caudal de lecturas que aparecen, el libro de Monteleone puede funcionar como un repertorio de invitaciones a leer, ya que, en muchos casos, los textos y obras referidos no sólo son analizados en relación a la propia vida sino también ampliamente reseñados. Se incluye al final una "Lista de obras mencionadas" (p. 211), con el objeto de ofrecer una guía alfabética para que el lector interesado pueda seguir explorando esos textos tan entrañables (y, quizás, por qué no, impulsarlo a armar su propia lista).

Juliana Regis

\section{REFERENCIAS}

Giordano, A. (2015). La resistencia a la ironía: notas desde (hacia) los ensayos de Borges. Variaciones Borges, 40 (1), pp. 99-113. Recuperado de http://www.borges.pitt.edu/sites/default/files/Giordano.pdf 